and those of establishing the settlor's intent and revocation could be most efficiently handled by a codification similar to that of New Jersey. ${ }^{35}$

Finally it may be urged that the savings-account trust is a useful device because of the simplicity of its operation over other forms of estate transfer. ${ }^{36} \mathrm{It}$ eliminates many expenses of administration, and it provides a simple solution to routine problems of cash management and estate transfer.

${ }^{25}$ N.J. Rev. Stat. (1954) § 17:9A-216. Consult 4 Powell, Real Property $\S 571$, at 437 (1954) for problems left unresolved by the New Jersey codification.

${ }^{36}$ A minimum of nine months is required to wind up an estate in which a will is involved. IIl. Rev. Stat. (1955) c. $3, \S 242$. A contest may postpone distribution for a number of years. Distribution under the Illinois "small estates" provision is of limited use because its relatively informal procedure is available only for estates of less than $\$ 1,000.00$. III. Rev. Stat. (1954) c. $3,8 \cdot 478$.

\title{
VOTING ELIGIBILITY UNDER NLRA §9(c)(3) OF UNREPLACED ECONOMIC STRIKERS SUBJECT TO DISCHARGE FOR WRONGFUL CONDUCT
}

Section 9(c)(3) of the National Labor Relations Act, as amended, ${ }^{1}$ provides, in part, that "[e]mployees on strike who are not entitled to reinstatement shall not be eligible to vote" in a representation election. The Court of Appeals for the District of Columbia was recently called upon to make the first judicial determination of the impact of this provision on the voting eligibility of non-replaced strikers guilty of misconduct during a strike. ${ }^{2}$

While an economic ${ }^{3}$. strike against the Union Manufacturing Company was in progress, an election was held to determine whether the American Federation of Hosiery Workers, A.F. of L., was to be certified as the employees' bargaining representative. The company challenged the voting eligibility of a number of the strikers on the ground of their misconduct ${ }^{4}$ during the strike. The disputed

r 61 Stat. 136 (1947), 29 U.S.C.A. § 151 (Supp., 1955).

2 Union Mfg. Co. v. NLRB, 221 F. 2d 532 (App. D.C., 1955), cert. denied 349 U.S. 921 (1955).

${ }^{3}$ The NLRB has distinguished between "unfair labor practice" strikes, i.e., strikes provoked or prolonged by an employer's unfair labor practice, and "economic" strikes, i.e., strikes called to obtain economic benefits such as changes in wages, hours or other working conditions. See NLRB v. A. Sartorius \& Co., 140 F. 2d 203 (C.A. 2d, 1944). The primary importance of the distinction is in its bearing on an employer's right to replace strikers. An employer is at liberty permanently to replace "economic" strikers. E.g., NLRB v. Mackay Radio \& Telegraph Co., 304 U.S. 333 (1938). In contrast, strikers in an "unfair labor practice" strike are entitled to reinstatement even if they have been replaced. E.g., Wheatland Electric Cooperative, Inc. v. NLRB, 208 F. 2d 878 (C.A. 10th, 1953), cert. denied 347 U.S. 966 (1954). Unless otherwise indicated, ensuing discussion will have reference to "economic" strikes and strikers.

"Judge Danaher's dissenting opinion states that the strikers were charged with "debarment, violence, mass picketing, and generally lawless conduct on the picket line." Union Mfg. Co.v. NLRB, 221 F. 2d 532, 537 (App. D.C., 1955), cert. denied 349 U.S. 921 (1955). Such acts of misconduct, if proven, are sufficient to warrant a denial of reinstatement. NLRB v. Perfect Circle Co., 162 F. 2d 566 (C.A. 7th, 1949) (debarment); NLRB v. Ohio Calcium Co., 
votes turned out to be decisive, and, the challenges having been overruled by the Board and the union certified, the company refused to bargain with the union. On appeal from the Board's order adjudging this to be an unfair labor practice, the company supported its position by a literal reading of section 9(c)(3), urging that since the strikers because of their misconduct were not "entitled to reinstatement" they were also ineligible to vote. The Board rejected this literal construction on the ground that the legislative history showed that the section's sole purpose was to bar from voting only such strikers as had actually been replaced. The court, with Judge Danaher dissenting, adopted the Board's construction and ordered enforcement. ${ }^{5}$

The court's justification for recourse to the legislative history is open to question, ${ }^{6}$ since the statutory language seems clear. Reference to the legislative history in this case, however, is in accord with the general tendency of the Board and the courts to take some liberties with statutory language which appears inconsistent with a purpose revealed in or constructed from the legislative history. ${ }^{7}$ In any event, the legislative history of section $9(c)(3)$ casts very little light on the question here involved because debate centered on the problem of determining the right to vote as between economic strikers and their replacements. The proponents of this section were severely critical ${ }^{8}$ of the Board's prior

133 F. 2d 721 (C.A. 6th, 1943) (violence); W. T. Rawleigh Co. v. NLRB, 190 F. 2d 832 (C.A. 7th, 1951) (mass picketing). In general, the term "strike misconduct" has reference to two categories of activity: First, conduct proscribed by the Act such as striking prior to the expiration of the 60-day "cooling off" period required by section $8(d)(4)$, and second, activity which, though not prohibited, is not protected by the Act and may be illegal under state or local law. This latter category comprehends misconduct such as violence and similarly coercive activity.

5 The seriousness of the misconduct involved apparently was considered immaterial as the court held that the Board was correct as a matter of law in overruling without a hearing the employer's challenges. For the purposes of this note, further references to misconduct will assume that it is of such a type as to warrant discharge or denial of reinstatement,

- In justifying resort to the legislative history, the court said: "In the light of these opposing contentions [by the Board and the company] we think the disputed sentence is ambiguous. On the face of it both contentions have reasonable support. Since the sentence upon its face is ambiguous we turn to the legislative history to try to ascertain its meaning from its purpose." Union Mfg. Co. v. NLRB, 221 F. 2d 532, 534 (App. D.C., 1955).

${ }^{7}$ The Supreme Court has made extremely free use of extrinsic aids in interpreting labor legislation. See Ass'n of Westinghouse Employees v. Westinghouse Electric Corp., 348 U.S. 437, 445-49 (1955) (committee reports, debates and hearings); Brooks v. NLRB, 348 U.S. 96, 100 (1954) (committee reports and debates); NLRB v. Denver Bldg. Council, 341 U.S. 675, 686-87 (1951) (conference reports, debates and hearings). In a non-labor case, Harrison v. Northern Trust Co., 317 U.S. 476 (1943), the Court held that it was reversible error for a lower court to refuse to consider the legislative history of the statute there involved, even though the relevant provision was on its face unambiguous. For a general discussion of the federal courts' use of legislative history consult A Re-evaluation of the Use of Legislative History in the Federal Courts, 52 Col. L. Rev. 125 (1952).

- Consult, e.g., the remarks of Senator Ball, 2 Legislative History of the Labor-Management Relations Act 957 (1948) (hereinafter cited as "Legis. Hist."). 
determination. Originally the Board had decided that strikers but not their replacements were to be considered eligible to vote in a representation election: ${ }^{9}$ In 1941 in the Wurlitzer ${ }^{10}$ case the Board modified its position and permitted both groups to vote. Since an employer is not required to take back strikers who have been permanently replaced, ${ }^{11}$ the later Board policy created, in the words of one of the Taft-Hartley supporters, "the ridiculous situation of a thousand persons voting for a bargaining agent for only 500 jobs."12 Section $9(c)(3)$ was intended to correct this situation by denying strikers who have been permanently replaced (and thus, under the Mackay 13 doctrine, are "not entitled to.reinstatement") the right to vote. ${ }^{14}$ It would seem to follow that the general purpose underlying the section was to accord voting rights. only to those strikers whose expectancy of continued employment in a bargaining unit is sufficiently high to give them a clear-cut interest in the selection of the bargaining representative. ${ }^{15}$

In view of this general purpose a determination of the voting eligibility of strikers who are subject to discharge for cause as well as replacement would appear to involve an assessment of the job expectancies of such strikers. This determination would also involve two countervailing factors which might justify voting ineligibility despite a high job expectancy on the part of such strikers. First, there is a possibility that recognition of voting eligibility for undischarged misconduct strikers would unjustifiably confront the employer with the troublesome alternatives of either (a) discharging strikers prior to an election, even though there had not been adequate time to identify wrongdoers and to determine whether their discharge was justified by legal and business considerations,

${ }^{9}$ A. Sartorius \& Co., 10 N.L.R.B.493 (1938).

${ }^{10}$ Rudolph Wurlitzer Co., 32 N.L.R.B. 163 (1941).

"1 NLRB v. Mackay Radio \& Telegraph Co., 304 U.S. 333 (1938).

122 Legis. Hist. 1102.

${ }^{13}$ NLRB v. Mackay Radio \& Telegraph Co., 304 U.S. 333 (1938).

${ }^{14}$ One explanation for the section's not being phrased in terms of replaced strikers may be found in the distinction between "economic" and "unfair labor practice" strikers. See note 3 supra. To have worded the sentence in terms of replacement would have denied replaced.workers in the latter group voting eligibility, a result the adopted terminology avoids. The allocation of voting rights embodied in section 9 (c)(3) was severely criticized as being a union-busting measure, Senator Murray's comments being typical in this respect. 2 Legis. Hist. 1041. For an appraisal of section 9(c)(3)'s effect, consult Right To Vote during an Economic Strike, 16 U. of Chi. L. Rev. 537 (1949).

Amendments to the Taft-Hartley Act to eliminate the alleged "union-busting" aspects of section 9(c)(3) were first proposed in President Eisenhower's State of the Union message of 1954. 100 Cong. Rec. 128 (1954). The changes suggested would have prevented a rival union from challenging the incumbent striking union's status as bargaining representative for a period of four months and would have prohibited such challenge by the employer for the length of the strike or a period of one year, whichever was shorter. Though legislation embodying these proposals was introduced by Senator Smith, 100 Cong. Rec. 93 (1954), the bills faile to pass both Houses.

${ }^{15}$ In addition to excluding strikers who have been replaced, the statutory language clearly is broad enough to cover strikers who have been discharged for cause and thus, under section 10(c), may not be reinstated by Board order. \& a! 
or (b) losing his right to discharge because his inaction had permitted the wrongdoers to vote and thereby had implied that they would continue to be part of the labor force. Secondly, the desirability of using disenfranchisement as a sanction against strike misconduct might be considered as overriding the objective of equating voting rights with job expectancies. Neither the Board nor the court dealt adequately with the foregoing considerations, which are discussed below.

An unreplaced striker who has not been guilty of misconduct has, while not an absolute right to reinstafement at the termination of a strike, ${ }^{16}$ a high expectancy of reinstatement, subject primarily to the employer's need for his services ${ }^{17}$ and his continued capacity to do the work. ${ }^{18}$ His post-strike job expectancy is thus sufficient to accord him voting rights. Where, however, the unreplaced striker has engaged in misconduct, his expectancy is subject to an additional contingency, namely, that the employer may exercise his right to discharge him. Although this added contingency reduces the probability of reinstatement for the culpable employees, it is difficult to determine what weight should be given to it. Whether it is to be taken into account in determining voting eligibility should depend in part on whether there is any justification for the employer's failure to clarify the reinstatement expectancies of the misconduct striker by either exercising or clearly waiving his discharge rights.

The dissenting opinion attempted to justify such inaction on the ground that requiring the employer to discharge prior to election any misconduct striker whom he wishes to disenfranchise involves the risk of an unfair labor practice (a) if the employer mistakenly discharges an innocent employee ${ }^{19}$ or (b) if the

${ }^{16}$ See NLRB v. Industrial Cotton Mills, 208 F. 2d 87, 92 (C.A. 4th, 1953), cert. denied 347 U.S. 935 (1954), where the court stated that, in general, "an employer may freely discharge an employee, or refuse to reinstate an employee, for any reason, good, bad or indifferent, provided the discharge or refusal to reinstate does not cut across or deny some right or activity of the employee, guaranteed by the Act, such as collective bargaining, striking or joining a Union."

${ }^{17} \mathrm{~A}$ variety of factors may cause a reduction in the post-strike labor force with the result of there being fewer jobs available than there are strikers otherwise entitled to reinstatement. Here the employer cannot be required to take back strikers whom he does not need. See, e.g., NLRB v. Nat'l Die Casting Co., 207 F. 2d 344 (C.A. 7th, 1953) (technological changes reduced need for workers). But the Board may require the employer to place the names of unreplaced workers for whom jobs cannot be found on a preferential hiring list, filling jobs from this list as they become available on a basis of seniority. See, e.g., Earl I. Sifers, 92 N.L.R.B. 1221, 1238 (1951). But cf. Sax v. NLRB, 171 F. $2 d 769$ (C.A. 7th, 1948).

${ }^{18}$ An employer is not obliged to reinstate strikers not physically fit for work. NLRB v. Industrial Cotton Mills, 208 F. 2d 87 (C.A. 4th, 1953), cert. denied 347 U.S. 935 (1954); see NLRB v. Republican Publishing Co., 180 F. 2d 437, 440 (C.A. 1st, 1950).

19 There is some conflict among the circuits as to whether a mistaken discharge, if made in good faith, is an unfair labor practice. A majority hold that it is, and that a Board order of reinstatement may properly issue. NLRB v. Cambria Clay Products Co., 215 F, 2d 48 (C.A. 6th, 1954); NLRB v. Industrial Cotton Mills, 208 F. 2d 87 (C.A. 4th, 1953), cert. denied 347 U.S. 935 (1954); Salt River Valley Water Users Ass'n v. NLRB, 206 F. 2d 325 (C.A. 9th, 1953); Cusano v. NLRB, 190 F. 2d 898 (C.A. 3d, 1951). Contra: Local No. 3, United Packinghouse Workers, C.I.O. v. NLRB, 210 F. 2 d 325 (C.A. 8th, 1954), cert. denied 348 U.S. 822 (1954); Rubin Brothers Footwear, Inc. v. NLRB, 203 F. $2 d 486$ (C.A. 5th, 1953) (semble). 
Board in such a situation should interpret the discharge as an attempt to interfere with protected activity in the form of a strike. ${ }^{20}$ This ground is not persuasive. Such risks are inevitable whenever the employer decides to discharge a striker for alleged strike misconduct or other forms of alleged misconduct which are ultimately held to be protected activity. The fact that the employer must make his decision shortly before an election does not in and of itself constitute a reason for insulating him against such risks. An intervening election does not, in short, justify an employer's use of the Board's election procedure as a device for securing an advisory opinion as to the legality of contemplated disciplinary action.

The employer may, however, be faced with a situation where misconduct occurs so close in time to a scheduled election as to preclude the investigation and deliberation necessary for the prudent exercise of his right to discharge. In such a situation the employer may urge that the doubt which exists at the time of the election as to the culpable employee's future employment results not from procrastination, but from the employer's desire to exercise his rights intelligently and to comply with the law. In most cases, the Board's present procedures would obviate the necessity for a precipitous decision. Where acts of misconduct are attributable to the union, and thus constitute violations of the statute, the employer by filing an unfair labor practice charge may delay the election and thereby secure additional time to reach a decision. ${ }^{21}$ Where acts of coercion take place shortly prior to balloting the Board has held that it may set the election aside, ${ }^{22}$ and while the question has not been decided it would seem that the rationale which justifies setting an election aside might also justify postponement until the effects of the coercive activity have been dissipatedthus once again giving the employer time for deliberation. ${ }^{23}$

${ }^{20}$ Union Mfg. Co. v. NLRB, 221 F. 2d 532, 538 (App. D.C., 1955), cert. denied 349 U.S. 921 (1955). The cases cited by Judge Danaher on this point do not support an implication that a discharge for cause can be an unfair labor practice. They merely hold that the Board may properly determine whether a discharge was in fact for cause or whether it was an attempt to interfere with a strike by eliminating a union supporter.

${ }^{21}$ During the pendency of such a charge, the Board's usual practice is to postpone holding the election until the charge has been disposed of. See Columbia Pictures Corp., 81 N.L.R.B. 1313 (1949).

22 The rationale of the Board is that an election held in an "atmosphere of confusion and fear of reprisal ... renders impossible the rational, uncoerced selection of a bargaining representative." Diamond State Poultry Co., 107 N.L.R.B. 3, 6 (1953). See further G. H. Hess, Inc., 82 N.L.R.B. 463 (1949).

${ }^{23}$ In the unusual situation, where the misconduct, though sufficient to warrant discharge, does not justify postponing the election under the Board's present policy and does not constitute an unfair labor practice, there is apparently no existing procedure which would guarantee the employer reasonable time in which to act. However, considering the desirability of an expeditious determination of the unit representative, it would not seem advisable to establish a procedure for postponing the election merely to give the employer time to determine the identity of the culpable strikers and to reach a decision as to his position toward these strikers. At the same time, allowing the misconduct strikers to vote should not, in all cases, prejudice the employer's rights of discharge. Consult p. 313 infra. 
Whatever difficulties may confront an employer in unusual situations, in the Union Manufacturing case the acts of misconduct occurred respectively one and three months prior to the election, ${ }^{24}$ and there was no showing of any special obstacles in the way of a decision by the employer as to whether he would exercise his discharge rights. The absence of any such showing suggests that the employer may have been attempting both to retain his culpable employees and to disenfranchise them. To permit such an attempt to succeed would seem inconsistent with section 9(c) (3)'s basic purpose of equating job expectancy and voting rights.

It would appear to be equally inconsistent with this basic purpose to permit an employer to discharge strikers on the ground of misconduct occurring prior to election after the striker's voting rights were recognized as a result of the employer's inaction, unless such inaction were justified by unusual circumstances. Section 9(c)(3) was designed not only to permit employees with an expectancy of reinstatement to vote, but also to disenfranchise those without such expectancies. A strong argument can be made that in order to implement this purpose an employer who fails without good reason to destroy voting eligibility by discharge prior to an election should be barred from discharging strikers thereafter. Since his inaction preserved for the strikers the status of employees for voting purposes, the employer could justifiably be estopped from thereafter destroying this status on the basis of pre-election conduct. There would, accordingly, be strong reasons for applying the Board's condonation doctrines in the foregoing situation. ${ }^{25}$ Where, however, the employer's inaction results from an inability to ascertain which of the strikers have engaged in misconduct, he might, under a recent decision of the Board, protect himself by giving notice of

"Brief for the Board at 31.

${ }^{25}$ While condonation "may not lightly be presumed from mere silence or equivocal statements, but must clearly appear from some positive act by an employer indicating forgiveness and an intention of treating the guilty employees as if their misconduct had not occurred," NLRB v. Marshall Car Wheel \& Foundry Co., 218 F. 2d 409, 414 (C.A. 5th, 1955), the Boardand the courts-have found condonation in employers' acts which are not so clearly indicative of forgiveness as the permitting of a misconduct striker to vote. NLRB v. Wallick, $198 \mathrm{~F} .2 \mathrm{~d}$ 477 (C.A. 3d, 1952) (employer made provisions for strikers to sign as "employees" in a letter); Carey Salt Co., 70 N.I.R.B. 1099 (1946) (employer retained a misconduct striker's name on his seniority list); NLRB v. Reed \& Prince Mfg. Co., 118 F. 2d 874 (C.A. 1st, 1941), cert. denied 313 U.S. 595 (1941) (employer reinstated strikers guilty of similar misconduct); Stewart Die Casting Corp. v. NLRB, 114 F. 2d 849 (C.A. 7th, 1940), cert. denied 312 U.S. 680 (1941) (employer urged all striking employees to return without excluding those who had engaged in misconduct).

The condonation problem raised by the Union Mfg. decision is not often likely to arise. The sequence of events necessary would have to include (1) an economic strike, (2) an election held during this strike, (3) misconduct prior to the election, (4) failure to discharge for the misconduct prior to the election, (5) application for reinstatement by the employee, (6) postelection discharge or refusal to reinstate on the ground of the misconduct and (7) filing of an unfair labor practice charge against the employer. Given this configuration, however, the Board may conclude, in view of the condonation cases and the policy underlying section 9 (c) (3), that the right to discharge or to deny reinstatement has been waived. 
his intention to reserve his right to discharge pending the outcome of investigation. ${ }^{26}$ This would, of course, allow the employer later to discharge voters, but no system can guarantee the complete identity of the voting group with the post-strike labor force. ${ }^{27}$.

The foregoing discussion suggests that in the ordinary situation the alternatives facing employers confronted with strike misconduct do not justify any limitations on the policy of equating voting rights and job expectancy. Whether this general purpose should be qualified in order to use disenfranchisement of culpable strikers as an indirect sanction against misconduct, an argument pressed by the dissenter, ${ }^{28}$ is a more troublesome problem. An immediate difficulty, which was neglected in the judicial opinions and adumbrated by the Board's, is suggested by section 8 (d $)^{29}$ of the Act. This section, which prohibits strikes prior to the expiration of a 60-day "cooling off" period, also provides that an employee who strikes during this period shall lose his voting rights. This loss of voting eligibility is automatic and, unlike the position taken by the court in construing section $9(\mathrm{c})(3)$, does not depend on affirmative discharge action by the employer.

It might be urged that the express provision for disenfranchisement as a sanction against misconduct proscribed by section 8(d) impliedly excludes the use of this sanction against other forms of misconduct. This argument is, however, questionable for two reasons. First, other forms of misconduct such as violence, property destruction and sit-down strikes are at least as grave as strikes during the 60-day period. If the statute is interpreted as representing a deliberate choice by Congress between forms of misconduct sufficiently serious to bring disenfranchisement into play as an indirect sanction, the implied distinction between 60-day strikes and other forms of misconduct would be difficult to justify. Secondly, the legislative history suggests a more persuasive explanation for the specific concern of Congress with the voting eligibility of 60-day strikers and its contrasting silence concerning the eligibility of strikers guilty of other forms of strike misconduct. Strike misconduct such as violence had been held by the courts to be unprotected activity prior to the enactment of the Taft-Hartley Act. ${ }^{30}$ On the other hand, a strike during the 60 -day period was proscribed and designated as unprotected activity for the first time by the Taft-Hartley amend-

${ }^{26}$ In Merck \& Co., 110 N.L.R.B. 67 (1954), the Board held that where the employer offered reinstatement but expressly reserved the right to discharge strikers who had been guilty of misconduct, and upon conviction by a local court discharged such a misconduct striker, the right to discharge had not been waived by the conditional re-employment.

. ${ }^{27}$ The section's purpose is inevitably frustrated whenever the cause privileging an employer's denial of reinstatement arises after an election.

28 Union Mfg. Co. v. NLRB, 221 F. 2d 532, 540-41 (App. D.C., 1955), cert. denied 349 U.S. 921 (1955).

${ }^{29}$ National Labor Relations Act, as amended, $\S 8(d)(1), 61$ Stat. 140 (1947), 29 U.S.C.A. $\S 158$ (Supp., 1955).

${ }^{30}$ The leading case is NLRB v. Fansteel Metallurgical Co., 306 U.S. 240 (1939). 
ments. This fact tends to explain why Congress, after delineating the new category of unprotected activity, went on to deal with the sanctions which could be directed against such misconduct. This explanation is reinforced by the legislative history which shows that provisions expressly withdrawing the protection of the Act from employees guilty of other forms of misconduct were abandoned solely on the ground that established precedent made such provisions unnecessary. ${ }^{31}$

Whether the policy of using disenfranchisement as a sanction against misconduct, reflected in section 8(d), should be extended beyond the 60-day strike situation is thus a question left open by Congress. As the majority opinion suggests, the sanction is of doubtful value as a deterrent..$^{32}$ Moreover, to apply a disenfranchisement policy regardless of the gravity of the offense and regardless of the reinstatement expectancy of the culpable employee would frustrate the basic policy underlying section 9 (c)(3). To draw distinctions based on the gravity of the offense would make lesser inroads on that policy, but would in turn raise two objections. First, it would confront the Board with the necessity of drawing difficult and delicate distinctions ${ }^{33}$ without any statutory guide as to the relevant factors. Second, the necessity for a Board determination may seriously impede the expeditious selection of a bargaining agent if a decisive number of voters are challenged for strike misconduct. ${ }^{34}$

The foregoing examination of the factors relevant to the issue raised by the Union Manufacturing case raises a serious question as to whether the legislative history to which the Board and the court had resort justifies the result reached. Nevertheless, the deficiency in the statutory drafting produced a troublesome problem, and the court's resolution is supported by strong considerations of policy and practicality. The result of the decision is that an intervening election may force an employer to decide what to do about misconduct strikers somewhat earlier than he would otherwise be obliged to. But any detriment involved to either employer or employee would seem outweighed by the desirability of not disenfranchising employees whose interests may be directly affected by the choice of a bargaining agent.

"1 1 Legis. Hist. 562-63.

s2 Union Mfg. Co. v. NLRB, 221 F. 2d 532, 536 (App. D.C., 1955), cert. denied 349 U.S. 921 (1955).

${ }^{33}$ In NLRB v. Illinois Tool Works, 153 F. 2d 811 (C.A. 7th, 1946), the court stated its belief that "courts have recognized that a distinction is to be drawn between cases where employees engaged in concerted activities exceed the bounds of lawful conduct in 'a moment of animal exuberance' ... and those flagrant cases in which the misconduct is so violent or of such serious character as to render the employee unfit for further service." Ibid., at 815 . The difficult problem arises when the misconduct in question lies between these extremes.

34 In the instant case, out of a total of 157 ballots cast 82 were challenged on the ground of strike misconduct. Union Mfg. Co., 101 N.L.R.B. 1028 (1952). If the number of ballots challenged is sufficient to affect the result of the election, the regional director must investigate the challenges and issue a report. If exceptions are filed to this report a hearing may be ordered by the Board. NLRB, Rules and Regulations \$ 102.61 (1952). 